\title{
Article
}

\section{Tannylated Calcium Carbonate Materials with Antacid, Anti-Inflammatory, and Antioxidant Effects}

\author{
Sung-Yun Jung ${ }^{1}$, Heamin Hwang ${ }^{1}$, Han-Saem Jo ${ }^{1}$, Somang Choi ${ }^{2}$, Hak-Jun Kim ${ }^{2}$, Sung-Eun Kim ${ }^{2, *}$ and \\ Kyeongsoon Park $1, *$ (D)
}

1 Department of Systems Biotechnology, Chung-Ang University, Gyeonggi 17546, Korea; jsy0035@gmail.com (S.-Y.J.); heamin1997@naver.com (H.H.); luchiatkfkd@naver.com (H.-S.J.)

2 Department of Orthopedic Surgery and Nano-Based Disease Control Institute, Korea University Guro Hospital, \#148, Gurodong-ro, Guro-gu, Seoul 08308, Korea; chlthakd1029@naver.com (S.C.); dakjul@korea.ac.kr (H.-J.K.)

* $\quad$ Correspondence: sekim10@korea.ac.kr (S.-E.K.); kspark1223@cau.ac.kr (K.P.); Tel.: +82-2-2626-1999 (S.-E.K.); +82-31-670-3357 (K.P.)

check for updates

Citation: Jung, S.-Y.; Hwang, H.; Jo, H.-S.; Choi, S.; Kim, H.-J.; Kim, S.-E.; Park, K. Tannylated Calcium Carbonate Materials with Antacid, Anti-Inflammatory, and Antioxidant Effects. Int. J. Mol. Sci. 2021, 22, 4614. https://doi.org/10.3390/ijms22094614

Academic Editor: Cristina Marzano

Received: 30 March 2021

Accepted: 26 April 2021

Published: 28 April 2021

Publisher's Note: MDPI stays neutral with regard to jurisdictional claims in published maps and institutional affiliations.

Copyright: (c) 2021 by the authors. Licensee MDPI, Basel, Switzerland. This article is an open access article distributed under the terms and conditions of the Creative Commons Attribution (CC BY) license (https:/ / creativecommons.org/licenses/by/ $4.0 /)$.

\begin{abstract}
Calcium carbonate $\left(\mathrm{CaCO}_{3}\right)$-based materials have received notable attention for biomedical applications owing to their safety and beneficial characteristics, such as $\mathrm{pH}$ sensitivity, carbon dioxide $\left(\mathrm{CO}_{2}\right)$ gas generation, and antacid properties. Herein, to additionally incorporate antioxidant and anti-inflammatory functions, we prepared tannylated $\mathrm{CaCO}_{3}\left(\mathrm{TA}-\mathrm{CaCO}_{3}\right)$ materials using a simple reaction between tannic acid (TA), calcium $\left(\mathrm{Ca}^{2+}\right)$, and carbonate $\left(\mathrm{CO}_{3}{ }^{2-}\right)$ ions. TA-CaCO synthesized at a molar ratio of 1:75 (TA:calcium chloride $\left(\mathrm{CaCl}_{2}\right)$ /sodium carbonate $\left(\mathrm{Na}_{2} \mathrm{CO}_{3}\right)$ ) showed 3-6 $\mu \mathrm{m}$ particles, comprising small nanoparticles in a size range of $17-41 \mathrm{~nm}$. The TA-CaCO 3 materials could efficiently neutralize the acid solution and scavenge free radicals. In addition, these materials could significantly reduce the mRNA levels of pro-inflammatory factors and intracellular reactive oxygen species, and protect chondrocytes from toxic hydrogen peroxide conditions. Thus, in addition to their antacid property, the prepared $\mathrm{TA}-\mathrm{CaCO}_{3}$ materials exert excellent antioxidant and anti-inflammatory effects through the introduction of TA molecules. Therefore, $\mathrm{TA}-\mathrm{CaCO} \mathrm{O}_{3}$ materials can potentially be used to treat inflammatory cells or diseases.
\end{abstract}

Keywords: calcium carbonate $\left(\mathrm{CaCO}_{3}\right)$; tannic acid (TA); antacid; anti-inflammation; ROS scavenging activity; chondrocytes

\section{Introduction}

Inorganic minerals have been widely used in drug delivery systems for biomedical applications [1]. Calcium carbonate $\left(\mathrm{CaCO}_{3}\right)$, an inorganic biomineral, has been used as an antacid agent. It can be orally administered as a tablet, chewable tablet, capsule, or liquid. Furthermore, it has been used for the controlled and sustained delivery of chemical drugs [2-4], photosensitizers [5], and proteins [6,7] because of its biocompatibility and slow biodegradation [8]. $\mathrm{CaCO}_{3}$ is stable at physiological $\mathrm{pH}$, but can be dissociated under acidic conditions $[9,10]$. Owing to their $\mathrm{pH}$ sensitivity, $\mathrm{CaCO}_{3}$-based delivery systems concentrate drugs into targeted cancer tissues within the acidic tumor microenvironment (TME) [4,5,10]. In addition, these systems react with protons $\left(\mathrm{H}^{+}\right)$to neutralize the acid [11,12]. $\mathrm{CaCO}_{3}$ can generate carbon dioxide $\left(\mathrm{CO}_{2}\right)$ in the acidic TME, and this gas-generating property has extended its application as an ultrasound contrast agent for cancer imaging $[5,10]$. These previous studies have revealed the $\mathrm{pH}$ sensitivity, $\mathrm{CO}_{2}$ gas generation, and antacid properties of $\mathrm{CaCO}_{3}$ materials.

Polyphenol tannic acid (TA) is composed of five digalloyl ester groups that have been linked to a central glucose molecule, and exhibits various biological properties, such as antibacterial, anti-inflammatory, antioxidant, and anticancer activities [13,14]. Previous studies have revealed the TA-mediated scavenging of free radicals, leading to 
the inhibition of lipid oxidation and radical-mediated DNA damage $[13,15,16]$. Given their ability to undergo multiple interactions with various biomacromolecules (i.e., nucleic acids, peptides, proteins, and polysaccharides) through electrostatic and hydrogen bonding and/or hydrophobic interactions [17-21], TA-macromolecular complexes can be easily produced and used as surface modifiers on organic and inorganic substrates [22,23]. Thus, the TA-modified polymeric hydrogels and scaffolds greatly enhance anti-inflammatory effects in vitro or protect cells under reactive oxygen species (ROS) environments [23,24]. Moreover, as TA can coordinate with metal ions, it can be used to synthesize inorganic $\mathrm{Ag}$ and $\mathrm{Au}$ nanomaterials [25]. Our group recently prepared oxygen-generating calcium peroxide using TA through coordination between the catechol moieties of TA and calcium ions [26].

Based on these previous reports, we propose that the introduction of TA into $\mathrm{CaCO}_{3}$ materials can endow them with anti-inflammatory and antioxidant functions. $\mathrm{As}^{\mathrm{CaCO}_{3}}$ materials exert no anti-inflammatory or antioxidant functions, herein we fabricated tannylated $\mathrm{CaCO}_{3}$ (termed as TA-CaCO 3 ) materials via the coordination of TA to calcium $\left(\mathrm{Ca}^{2+}\right)$ ions and further nucleation of $\mathrm{CaCO}_{3}$ using carbonate ions $\left(\mathrm{CO}_{3}{ }^{2-}\right)$. We performed their physicochemical characterization and evaluated their antacid and antioxidant effects using colorimetric methods. In addition, we validated their in vitro antioxidant and anti-inflammatory properties in chondrocytes under inflammatory and ROS conditions.

\section{Results and Discussion}

\subsection{Preparation of $\mathrm{TA}-\mathrm{CaCO}_{3}$ Materials}

TA-CaCO${ }_{3}$ materials were synthesized by combining equimolar amounts of $\mathrm{Ca}^{2+}$ and $\mathrm{CO}_{3}{ }^{2-}$ at different concentrations with a fixed molar concentration of TA under constant stirring, as depicted in Figure 1. Given the tendency of TA to coordinate with metal ions $[25,27,28]$, TA interacts with $\mathrm{Ca}^{2+}$ ions and facilitates the nucleation of $\mathrm{CaCO}_{3}$ to form $\mathrm{TA}-\mathrm{CaCO}_{3}$ nanoparticles, which then agglomerate into microparticles due to the interactions between $\mathrm{TA}-\mathrm{CaCO}_{3}$ nanoparticles.

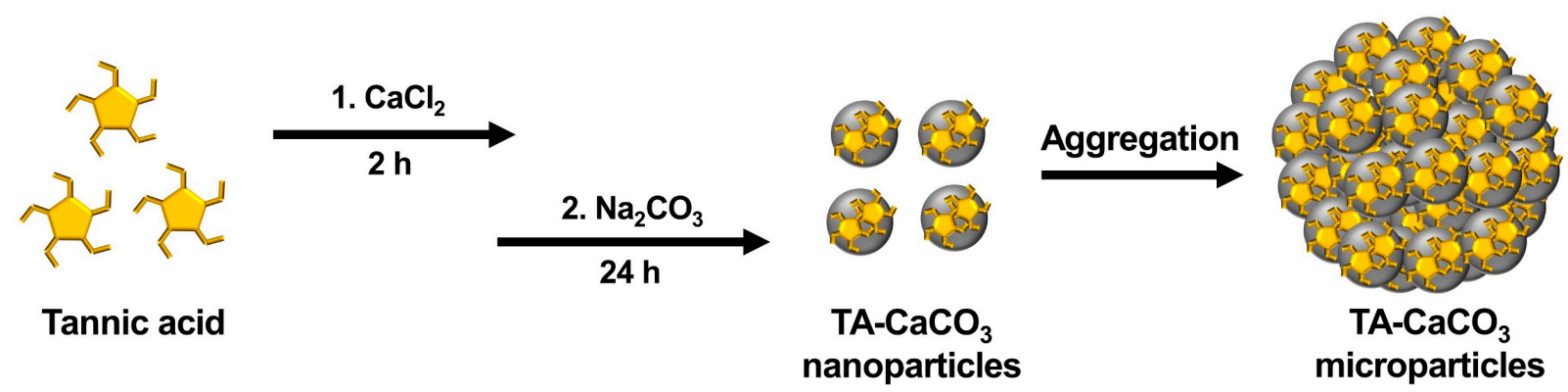

Figure 1. Schematic illustration of the synthesis of $\mathrm{TA}-\mathrm{CaCO}_{3}$ materials. TA was sequentially reacted with $\mathrm{CaCl}_{2}$ for $2 \mathrm{~h}$ and $\mathrm{Na}_{2} \mathrm{CO}_{3}$ for an additional $24 \mathrm{~h}$ in pure water $(\mathrm{pH}=7.0)$.

\subsection{Characterization of $\mathrm{TA}-\mathrm{CaCO}_{3}$ Materials}

The morphologies of the synthesized $\mathrm{TA}-\mathrm{CaCO}_{3}$ materials were examined using scanning electron microscopy (SEM). As shown in Figure S1, at 25 molar ratios of calcium chloride $\left(\mathrm{CaCl}_{2}\right)$ / sodium carbonate $\left(\mathrm{Na}_{2} \mathrm{CO}_{3}\right)$, aggregates comprising small TA-CaCO particles were predominantly observed, and very small amounts of micron-sized spherical TA- $-\mathrm{CaCO}_{3}$ particles were formed. More spherical TA- $-\mathrm{CaCO}_{3}$ microparticles were gradually observed as the molar ratio of $\mathrm{CaCl}_{2} / \mathrm{Na}_{2} \mathrm{CO}_{3}$ was increased to 75 . Interestingly, although spherical TA- $\mathrm{CaCO}_{3}$ microparticles were still observed when the molar ratios of TA and $\mathrm{CaCl}_{2} / \mathrm{Na}_{2} \mathrm{CO}_{3}$ were 100 or 150 , more irregular and broken $\mathrm{TA}-\mathrm{CaCO}_{3}$ particles were detected. These results suggested that small TA- $\mathrm{CaCO}_{3}$ particles were formed at lower molar ratios of $\mathrm{CaCl}_{2} / \mathrm{Na}_{2} \mathrm{CO}_{3}$ and that spherical and broken $\mathrm{TA}-\mathrm{CaCO}_{3}$ particles were more common at higher molar ratios of TA and $\mathrm{CaCl}_{2} / \mathrm{Na}_{2} \mathrm{CO}_{3}$. Based on SEM images, 
1:75 $\mathrm{TA}-\mathrm{CaCO}_{3}$ particles were selected for further experiments because they produced more spherical TA- $\mathrm{CaCO}_{3}$ microparticles than other $\mathrm{TA}-\mathrm{CaCO}_{3}$ particles.

Next, we investigated the particle size of the 1:75 TA-CaCO 3 materials and found it to range from approximately 3 to $6 \mu \mathrm{m}$ (Figure 2a and Figure S1). Interestingly, the magnified SEM images revealed the presence of small particles on the surface of the 1:75 TA-CaCO 3 materials. These individual small particles ranged from 17 to $41 \mathrm{~nm}$ in size, and were approximately $26.18 \pm 4.6 \mathrm{~nm}$ in diameter and spherical in shape (Figure 2b). SEM images revealed that the micron-sized TA-CaCO 3 materials consisted of small TA- $\mathrm{CaCO}_{3}$ nanoparticles, probably owing to agglomeration following interactions between individual small nanoparticles.

(a)

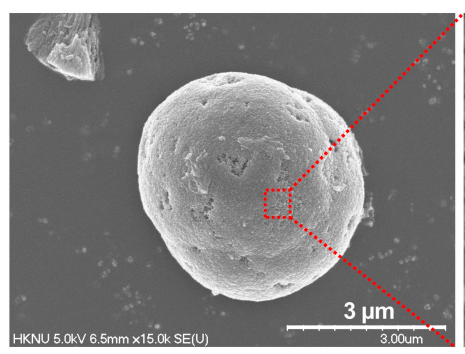

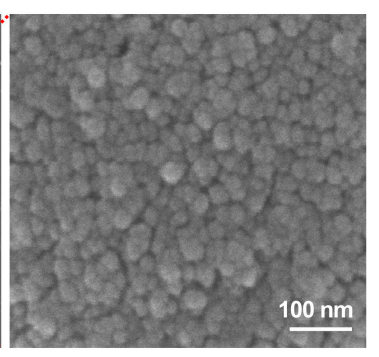

(b)

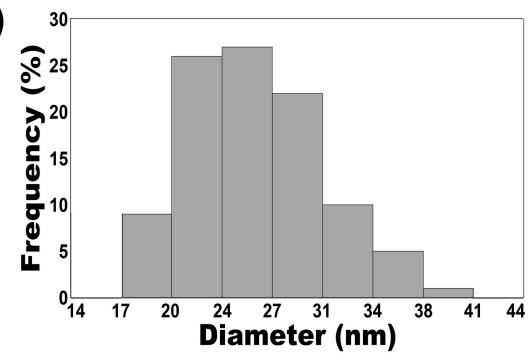

(c)
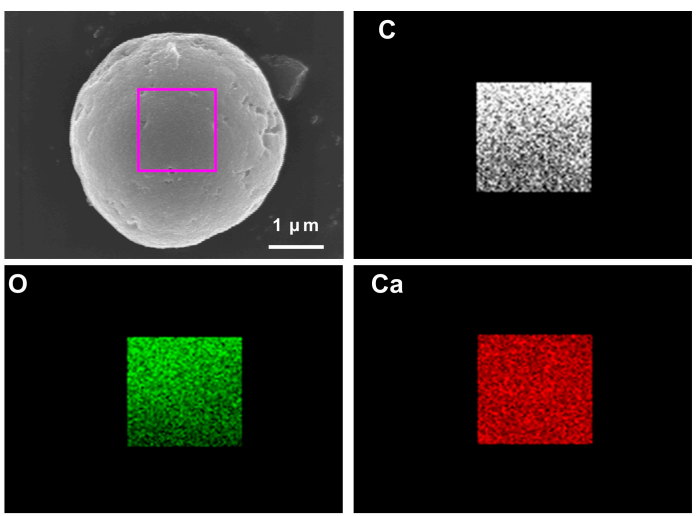

(d)
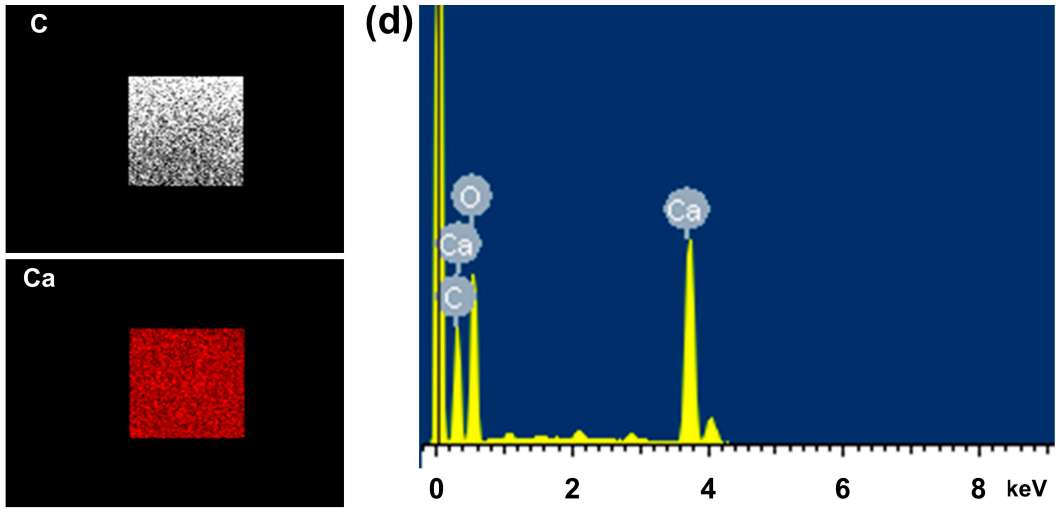

Figure 2. (a) The representative SEM images and magnified surface of $1: 75 \mathrm{TA}-\mathrm{CaCO}_{3}$ materials. The magnified SEM image revealed that the micron-sized $\mathrm{TA}-\mathrm{CaCO}_{3}$ materials comprised small $\mathrm{TA}-\mathrm{CaCO}_{3}$ nanoparticles. (b) Particle size distribution of the small $\mathrm{TA}-\mathrm{CaCO}_{3}$ nanoparticles of 1:75 $\mathrm{TA}-\mathrm{CaCO}_{3}$. (c) EDS mapping of elemental carbon ( $\mathrm{C}$; white), oxygen (O; green), and calcium (Ca; red). Scale bar: $1 \mu \mathrm{m}$. (d) EDS spectrum of 1:75 TA-CaCO 3 .

The preparation of TA- $\mathrm{CaCO}_{3}$ materials was confirmed using an SEM coupled with energy-dispersive (SEM-EDS) X-ray spectroscopy, inductively coupled plasma optical emission spectrometry (ICP-OES), Fourier transform infrared (FT-IR) spectroscopy, X-ray diffraction (XRD) patterns, and X-ray photoelectron spectroscopy (XPS). The EDS mapping and spectrum data revealed the presence of carbon, oxygen, and calcium on the surface of TA- $\mathrm{CaCO}_{3}$ materials (Figure 2c,d). Consistent with a previous report [29], the EDS spectrum showed the peaks of $\mathrm{K} \alpha(0.277 \mathrm{eV})$ corresponding to carbon, $\mathrm{K} \alpha(0.523 \mathrm{eV})$ corresponding to oxygen, and $\mathrm{K} \alpha(3.691 \mathrm{eV})$ and $\mathrm{L} \alpha(0.341 \mathrm{eV})$ corresponding to calcium. ICP-OES analysis showed that $0.1 \mathrm{mg}$ of $1: 75 \mathrm{TA}-\mathrm{CaCO}_{3}$ contained $18.6 \mu \mathrm{g}$ of TA and $81.4 \mu \mathrm{g}$ of $\mathrm{CaCO}_{3}$. The FT-IR spectrum of commercial $\mathrm{CaCO}_{3}$ showed the characteristic vibrations of carbonate ions (at 1805, 1410, 1090, and $874 \mathrm{~cm}^{-1}$ ) (Figure 3), as previously reported $[30,31]$. The preparation of $\mathrm{TA}-\mathrm{CaCO}_{3}$ materials was confirmed by the presence of the main asymmetric vibrations at 1460 and $1410 \mathrm{~cm}^{-1}$. However, the symmetric vibration at $725 \mathrm{~cm}^{-1}$ disappeared, implying that $\mathrm{TA}-\mathrm{CaCO}_{3}$ has an amorphous structure. Meanwhile, $\mathrm{TA}-\mathrm{CaCO}_{3}$ showed characteristic peaks at $3300-3600 \mathrm{~cm}^{-1}$ (O-H stretching), $1445 \mathrm{~cm}^{-1}$ (C-C stretching of benzene ring and methylene; $\mathrm{C}-\mathrm{O}$ stretching of phenolic), 
and $755 \mathrm{~cm}^{-1}$ (C-H torsion of benzene ring) [32], indicative of the presence of TA on the material.

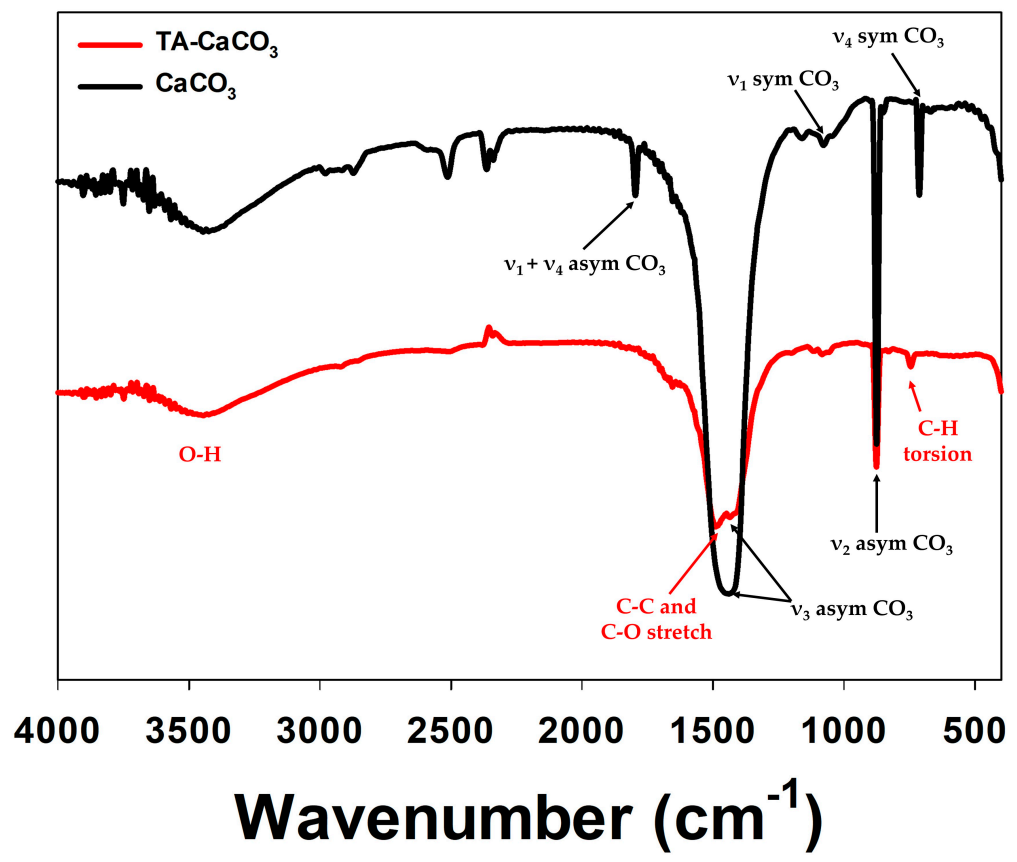

Figure 3. FT-IR spectra of commercial $\mathrm{CaCO}_{3}$ and $\mathrm{TA}-\mathrm{CaCO}_{3}$.

Next, commercial $\mathrm{CaCO}_{3}$ and synthesized TA- $\mathrm{CaCO}_{3}$ crystal phases were identified via XRD analysis (Figure 4a). $\mathrm{CaCO}_{3}$ exhibited the characteristic peaks, such as the plane of the calcite at $29.3^{\circ}(104)$, and the calcite crystal faces at $23.02^{\circ}(012), 35.9^{\circ}(110), 39.4^{\circ}(113)$, and $43.1^{\circ}(202)$, respectively. Meanwhile, the diffraction peaks of $\mathrm{TA}-\mathrm{CaCO}_{3}$ were observed at $24.8^{\circ}(110), 27.08^{\circ}(112), 32.7^{\circ}(114), 43.8^{\circ}(300), 49.1^{\circ}(304)$, and $50.08^{\circ}(118)$, respectively, and these diffraction peaks were consistent with the vaterite crystal faces [33,34]. Based on XRD data, we think that the prepared $\mathrm{TA}-\mathrm{CaCO}_{3}$ materials are the vaterite form of calcium carbonate.

(a)

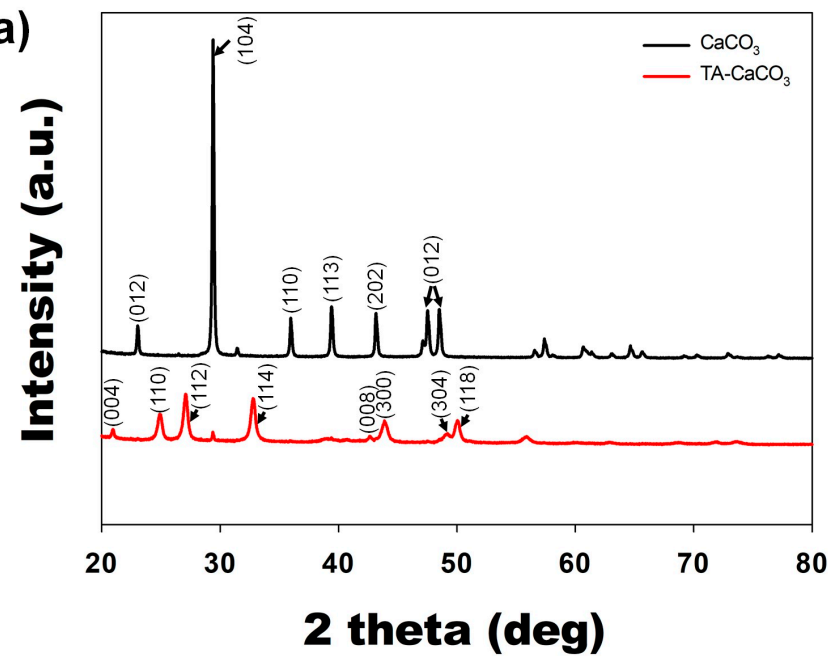

(b)

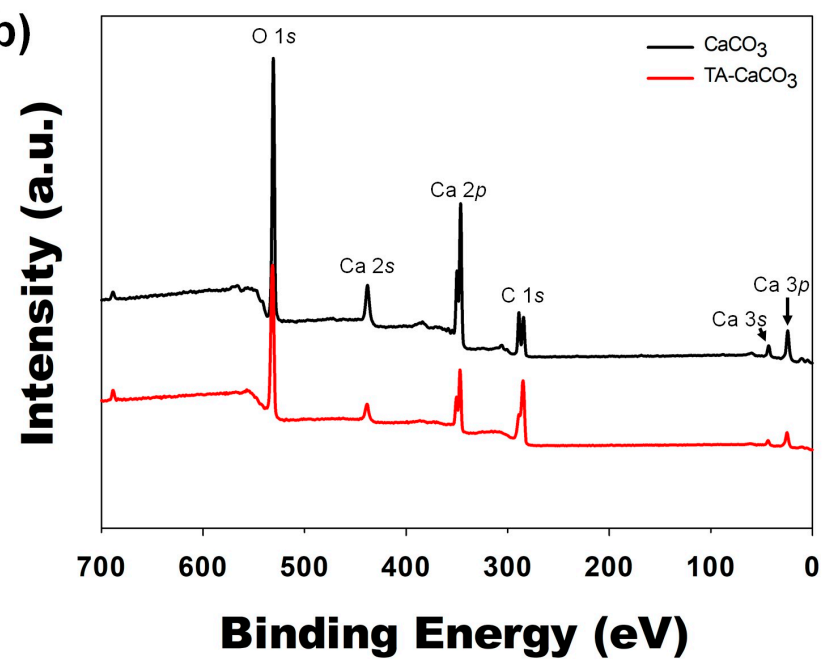

Figure 4. XRD and XPS analyses of commercial $\mathrm{CaCO}_{3}$ and $\mathrm{TA}-\mathrm{CaCO}_{3}$ materials. (a) XRD spectra of $\mathrm{CaCO}_{3}$ and $\mathrm{TA}-\mathrm{CaCO}_{3}$. (b) Wide scan XPS spectra recorded from $\mathrm{CaCO}_{3}$ and $\mathrm{TA}-\mathrm{CaCO}_{3}$.

XPS data revealed that $\mathrm{CaCO}_{3}$ and TA-CaCO 3 showed $\mathrm{Ca}, \mathrm{O}$, and $\mathrm{C}$ signals (Figure $4 \mathrm{~b}$ ). The binding energy peaks of these two materials appeared $\mathrm{O} 1 \mathrm{~s}$ at $531 \mathrm{eV}, \mathrm{Ca} 2 \mathrm{~s}$ at $441 \mathrm{eV}$, 
two Ca2p at 351 and $347.2 \mathrm{eV}$, and two $\mathrm{C} 1$ s peaks at $289.3 \mathrm{eV}\left(\mathrm{CO}_{3}\right.$ in the $\mathrm{CaCO}_{3}$ surface $)$ and $284.6 \mathrm{eV}$ (adventitious carbon peak), respectively. These data demonstrated the successful synthesis of $\mathrm{TA}-\mathrm{CaCO}_{3}$, and the synthesized $\mathrm{TA}-\mathrm{CaCO}_{3}$ materials are vaterite calcium carbonate.

\subsection{Antacid Effects of $\mathrm{TA}-\mathrm{CaCO}_{3}$}

$\mathrm{CaCO}_{3}$ exists as a stable crystalline solid at physiological $\mathrm{pH}$, but can be dissociated into ionic species at or below weakly acidic $\mathrm{pH}[5,9]$. Under acidic $\mathrm{pH}, \mathrm{CaCO}_{3}$ neutralizes acids by reacting with the proton $\left(\mathrm{H}^{+}\right)[11,12]$, and it has been used as an acid neutralizer [35].

To verify the antacid effects of TA-CaCO 3 materials, commercial $\mathrm{CaCO}_{3}$ and TA$\mathrm{CaCO}_{3}$ were dispersed in phosphate-buffered saline (PBS; physiological $\mathrm{pH}=7.4$ ) and simulated gastric fluid (SGF, pH 1.5) containing bromothymol blue (BTB). The color and absorption changes of BTB were monitored before and after the reaction, because BTB is a useful acid/base indicator to distinguish the acidity, neutrality, and alkalinity of an aqueous solution [36,37]. As shown in Figure 5a and Figure S2, the aqueous BTB solution without commercial $\mathrm{CaCO}_{3}$ and $\mathrm{TA}-\mathrm{CaCO}_{3}$ exhibited a blue color at $\mathrm{pH}=7.4$ and turned to a yellowish color in the presence of $\mathrm{SGF}(\mathrm{pH}=1.5) . \mathrm{CaCO}_{3}$ and $\mathrm{TA}-\mathrm{CaCO}_{3}$ showed a deep blue color of $\mathrm{BTB}$ at $\mathrm{pH}=7.4$, indicating the slight $\mathrm{pH}$ increases of the solution following the degradation of $\mathrm{CaCO}_{3}$ and $\mathrm{TA}-\mathrm{CaCO}_{3}$, even at $\mathrm{pH}=7.4$. In contrast, the yellowish BTB solution at $\mathrm{pH}=1.5$ turned to a bluish green color after the reaction with $\mathrm{CaCO}_{3}$ and $\mathrm{TA}-\mathrm{CaCO}_{3}$, indicating that the $\mathrm{pH}$ of the solution increased to a nearly neutral $\mathrm{pH}$ (approximately 7). Consistent with these color changes, the $\lambda_{\max }$ shift of BTB occurred from $615 \mathrm{~nm}$ at $\mathrm{pH}=7.4$ to $433 \mathrm{~nm}$ under SGF ( $\mathrm{pH}=1.5)$ (Figure $5 \mathrm{~b})$. However, the absorptions of both $\mathrm{CaCO}_{3}$ and $\mathrm{TA}-\mathrm{CaCO}_{3}$ groups increased at $615 \mathrm{~nm}$, while the $\lambda_{\max }$ of $\mathrm{BTB}$ at $\mathrm{pH}=1.5$ was blue-shifted from $433 \mathrm{~nm}$ to $403 \mathrm{~nm}$, implying the $\mathrm{pH}$ increases of the solutions after reacting with two kinds of $\mathrm{CaCO}_{3}$ materials. Meanwhile, $\mathrm{TA}-\mathrm{CaCO}_{3}$ showed significantly higher absorbance below $400 \mathrm{~nm}$ at both $\mathrm{pH}=1.5$ and $\mathrm{pH}=7.4$, indicating the presence of TA in the solutions. Furthermore, $\mathrm{TA}-\mathrm{CaCO}_{3}$ had a lower absorbance than commercial $\mathrm{CaCO}_{3}$ at $615 \mathrm{~nm}$. This is attributed to the fact that $\mathrm{TA}-\mathrm{CaCO}_{3}$ contained a lower amount of $\mathrm{CaCO}_{3}$ than commercial $\mathrm{CaCO}_{3}$.

(a)

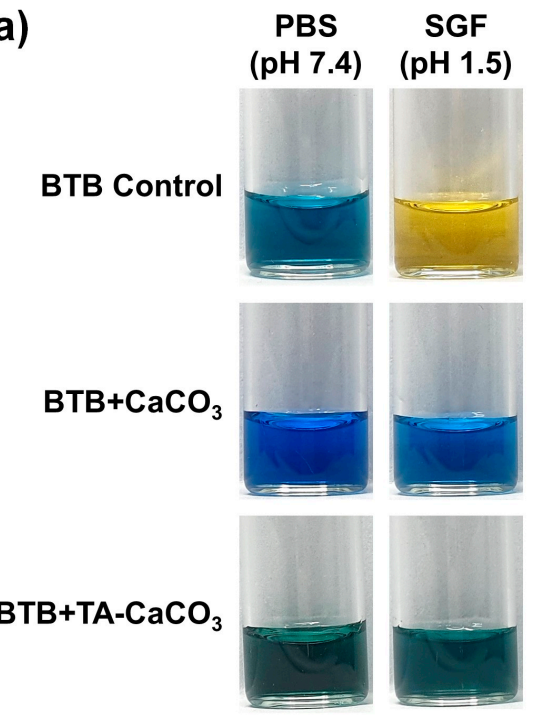

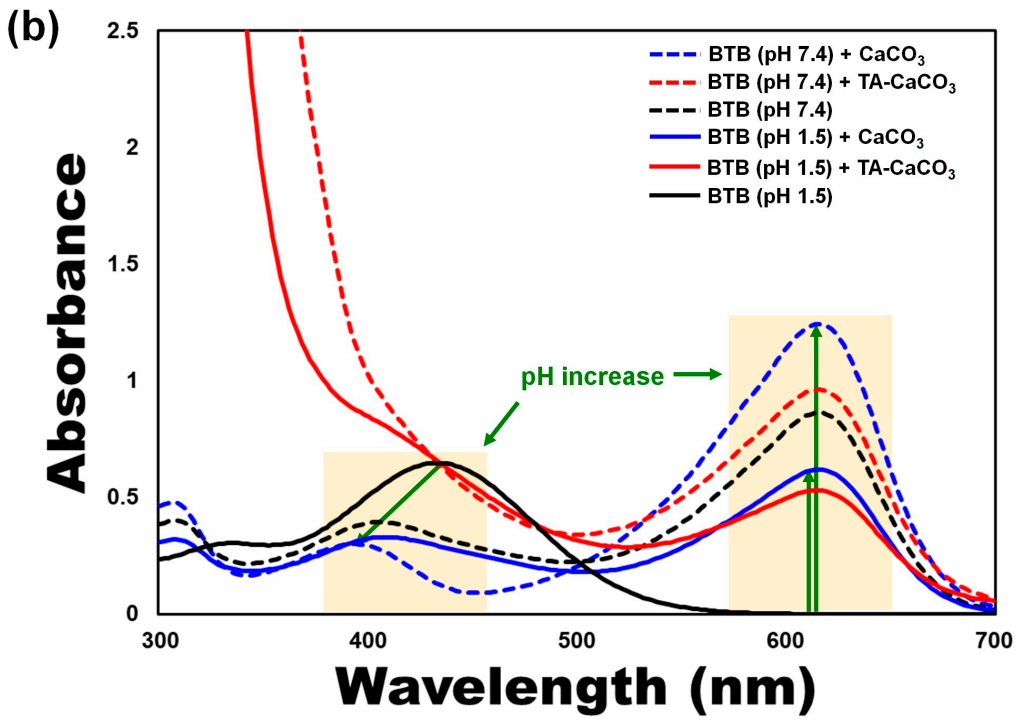

Figure 5. Antacid effects of $\mathrm{TA}-\mathrm{CaCO}_{3}$ using the colorimetric bromothymol blue (BTB) method. (a) Color changes and (b) $\mathrm{UV} /$ vis spectra of BTB under PBS ( $\mathrm{pH}=7.4$ ) and simulated gastric fluid (SGF, $\mathrm{pH}=1.5$ ) after treatment with commercial $\mathrm{CaCO}_{3}$ and 1:75 $\mathrm{TA}-\mathrm{CaCO}_{3}$. Green-colored arrows indicate a $\mathrm{pH}$ increase. 


\subsection{Antioxidant Effects of $\mathrm{TA}-\mathrm{CaCO}_{3}$}

The antioxidant effects of TA-CaCO 3 were determined using the stable free radical 2,2-diphenyl-1-picrylhydrazyl (DPPH) [38]. As shown in Figure 6, the DPPH solution showed a deep violet color, with an absorbance at approximately $520 \mathrm{~nm}$, owing to the delocalization of the spare electron over the molecule [38]. $\mathrm{CaCO}_{3}$-treated DPPH solution also had a deep violet color and an absorption band at around $520 \mathrm{~nm}$, indicating that $\mathrm{CaCO}_{3}$ had no antioxidant effect. In contrast, $\mathrm{TA}-\mathrm{CaCO}_{3}$-treated DPPH solution turned yellowish in color and lost its absorbance at $520 \mathrm{~nm}$. This loss of violet color might be attributed to the presence of TA molecules within TA-CaCO 3 because TA molecules have an effective radical-scavenging activity, as its hydroxyl groups easily reduce the free radicals of DPPH $[39,40]$. These data imply that TA-CaCO 3 materials have antioxidant properties and effective ROS-scavenging activity.

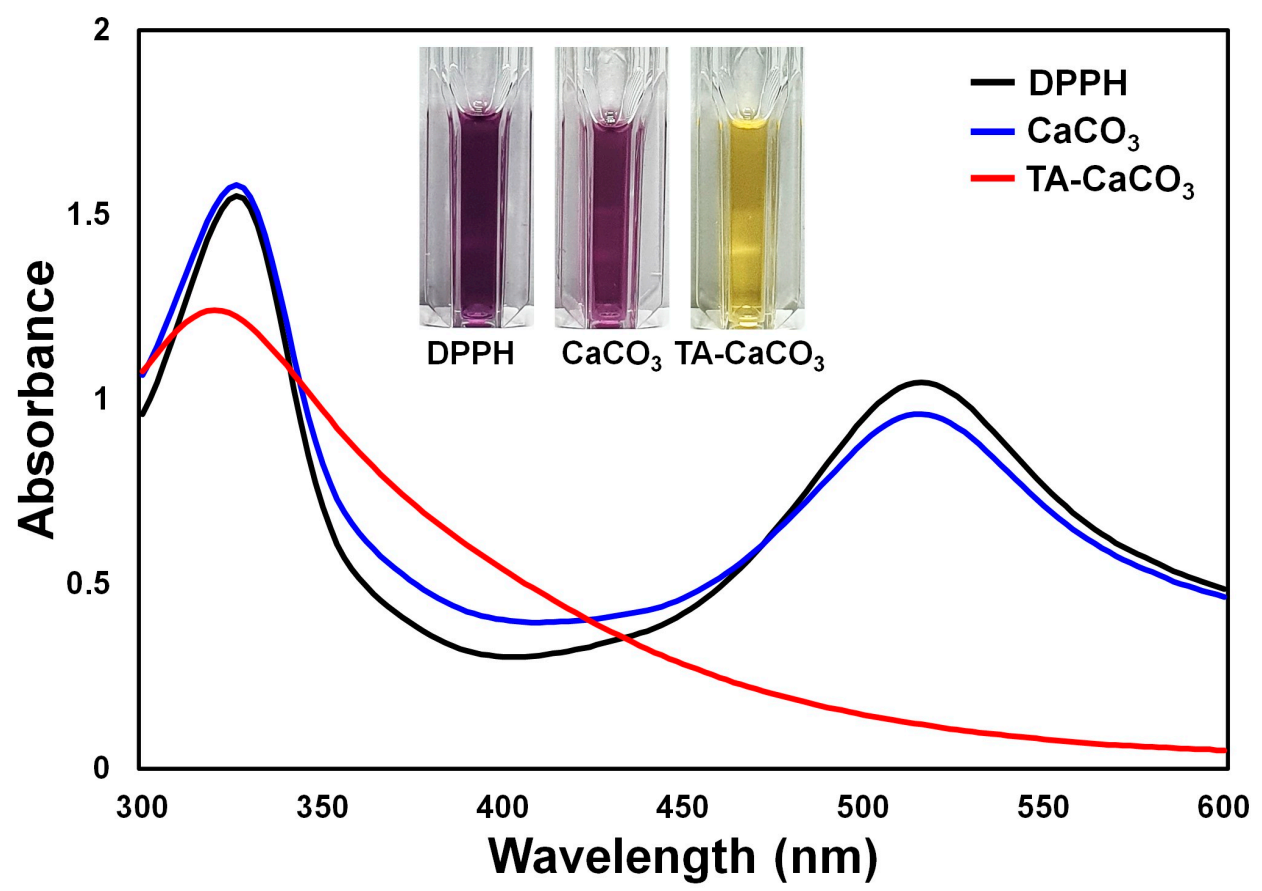

Figure 6. Antioxidant effects of $\mathrm{TA}-\mathrm{CaCO}_{3}$ determined using the colorimetric DPPH method. Changes in the color and UV/vis spectra of DPPH after treatment with commercial $\mathrm{CaCO}_{3}$ and 1:75 TA- $\mathrm{CaCO}_{3}$. Inset: Photos of the DPPH solution treated with commercial $\mathrm{CaCO}_{3}$ and 1:75 $\mathrm{TA}-\mathrm{CaCO}_{3}$.

\subsection{In Vitro Anti-Inflammatory Effects of $\mathrm{TA}-\mathrm{CaCO}_{3}$ in Inflamed Chondrocytes}

The cytotoxicity study of TA-CaCO $\mathrm{C}_{3}$ was examined against normal chondrocytes. Figure S3 revealed that chondrocytes maintained their cell viabilities above $90 \%$ up to a $100 \mu \mathrm{g} / \mathrm{mL}$ concentration, indicating that $\mathrm{TA}-\mathrm{CaCO}_{3}$ is non-toxic.

In addition to antioxidant effects, TA molecules also exhibit anti-inflammatory properties [41]. We examined the in vitro anti-inflammatory effects of $\mathrm{TA}-\mathrm{CaCO}_{3}$ by analyzing the mRNA expression of pro-inflammatory factors, such as cyclooxygenase-2 (COX-2), interleukin (IL)-1 $\beta$, IL-6, matrix metalloproteinase (MMP)-3, MMP-13, and tumor necrosis factor (TNF)- $\alpha$ in lipopolysaccharide (LPS)-stimulated chondrocytes, because LPS treatment leads to the overexpression of these pro-inflammatory factors [41-43].

As shown in Figure 7, LPS significantly upregulated the mRNA expression of all pro-inflammatory cytokines on day three compared to the control treatment. However, the mRNA levels of these pro-inflammatory cytokines were efficiently suppressed following treatment with $\mathrm{TA}-\mathrm{CaCO}_{3}$ in a dose-dependent manner. These results indicate that TA$\mathrm{CaCO}_{3}$ materials are highly effective in suppressing pro-inflammatory factors in LPS- 
stimulated chondrocytes. Consistent with previous studies, the present study also supports the anti-inflammatory effects of TA-based materials [24,44].

(a)
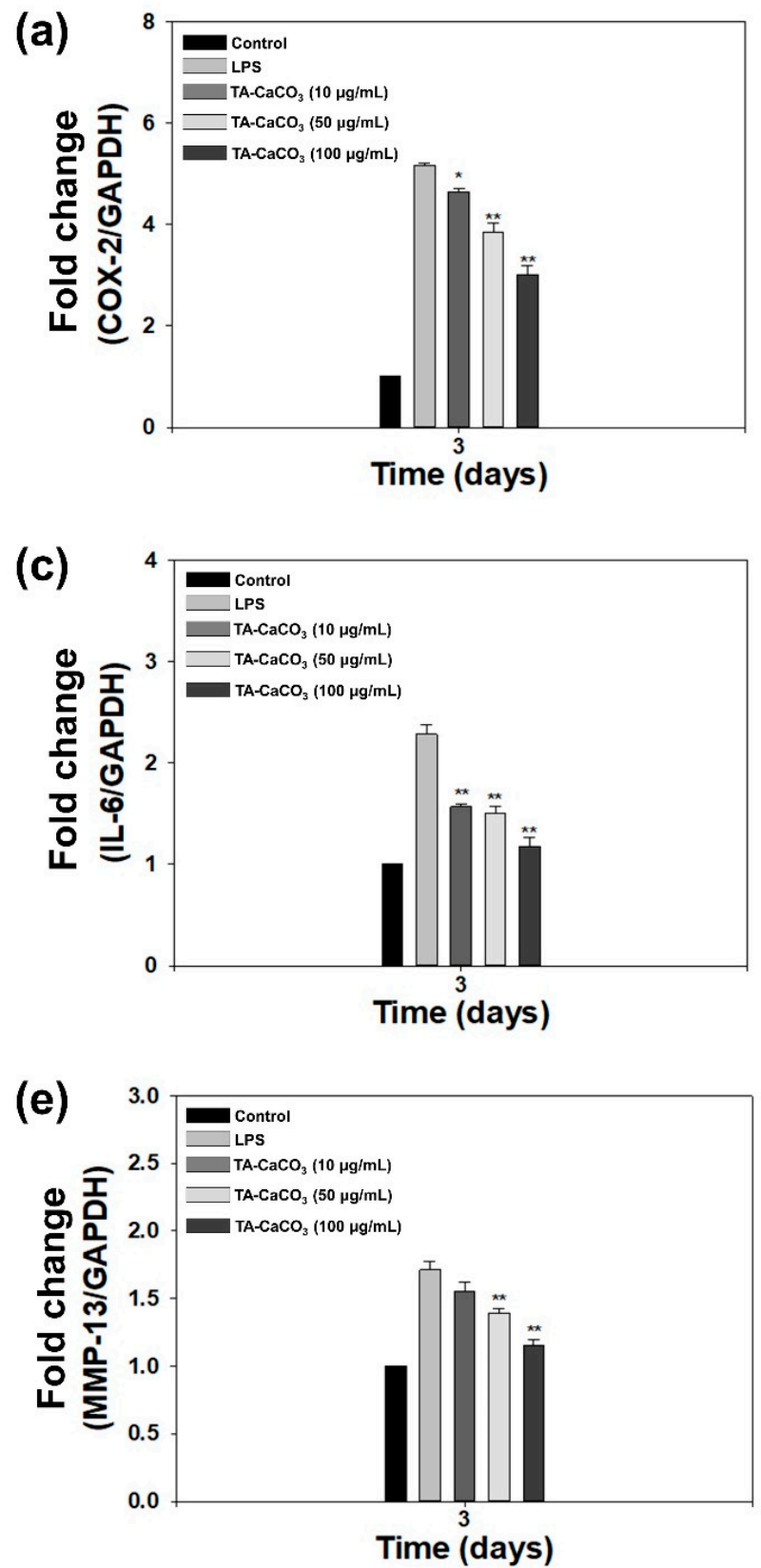

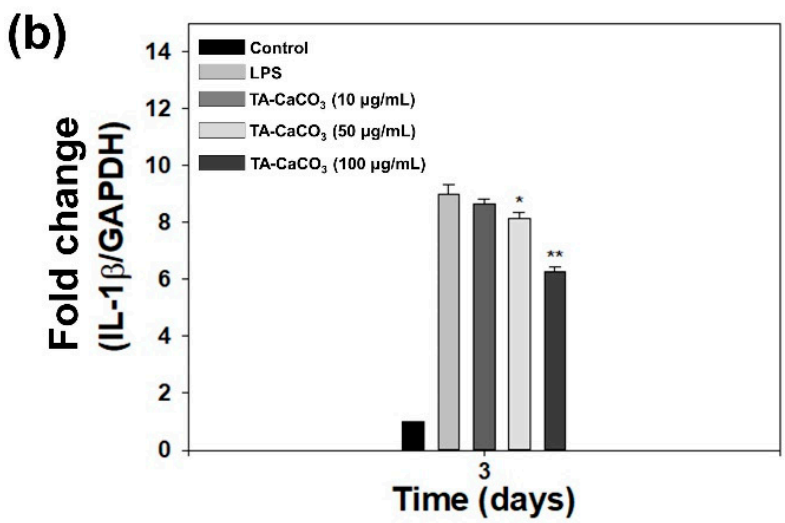

(d)

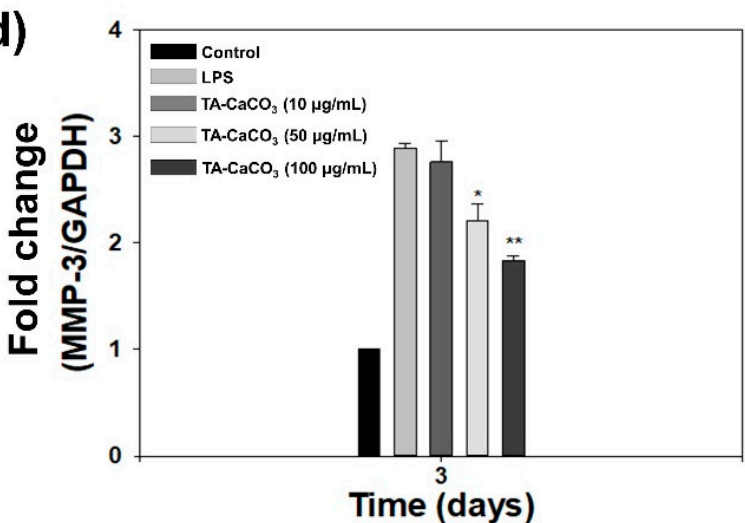

(f)

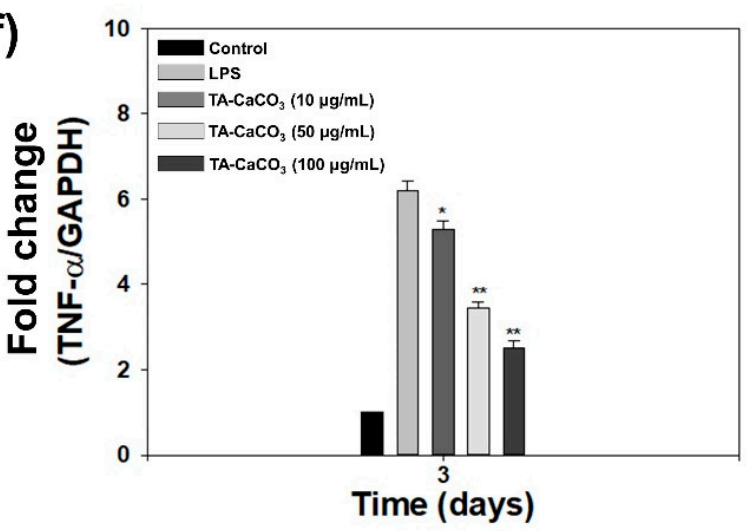

Figure 7. In vitro anti-inflammatory effects of 1:75 TA-CaCO 3 in inflamed chondrocytes. The mRNA levels of pro-inflammatory factors, including (a) cyclooxygenase-2 (COX-2), (b) interleukin-1 $\beta$ (IL-1 $\beta$ ), (c) IL-6, (d) matrix metalloproteinase-3 (MMP-3), (e) MMP-13, and (f) tumor necrosis factor- $\alpha$ (TNF- $\alpha$ ) in LPS-stimulated chondrocytes on day three. Data are represented as the mean $\pm \operatorname{SD}(n=5) .{ }^{* *} p<0.01$ and $* p<0.05$.

\subsection{In Vitro Antioxidant and Protective Effects of $\mathrm{TA}-\mathrm{CaCO} 3$ in $\mathrm{H}_{2} \mathrm{O}_{2}$-Treated Chondrocytes}

The exogenous treatment of cells with $\mathrm{H}_{2} \mathrm{O}_{2}$ results in the induction of oxidative stress and produces intracellular ROS [45,46]. To demonstrate the antioxidant activities of TA$\mathrm{CaCO}_{3}$ at the cellular level, $\mathrm{H}_{2} \mathrm{O}_{2}(300 \mu \mathrm{M})$-pretreated chondrocytes were incubated with different concentrations of $\mathrm{TA}-\mathrm{CaCO}_{3}$ extracts, and the intracellular ROS level was detected from the fluorescence signal of $2^{\prime}, 7$-dichlorodihydrofluorescein diacetate (DCFDA) using a confocal laser scanning microscope. As shown in Figure 8a, no fluorescence was observed 
in normal cells, whereas a strong signal was detected in cells treated with $300 \mu \mathrm{M}$ of $\mathrm{H}_{2} \mathrm{O}_{2}$ alone. The treatment of the extracts containing different concentrations of $\mathrm{TA}-\mathrm{CaCO}_{3}$ led to a remarkable decrease in fluorescence intensities, indicative of the excellent scavenging of intracellular ROS by TA- $\mathrm{CaCO}_{3}$.

(a)

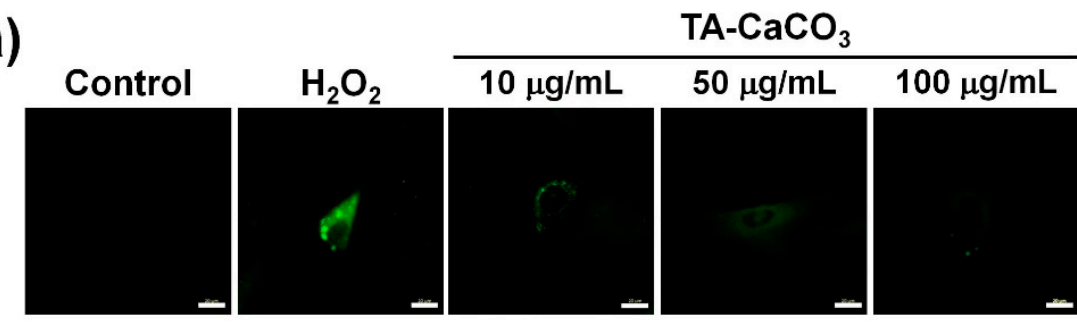

(b)

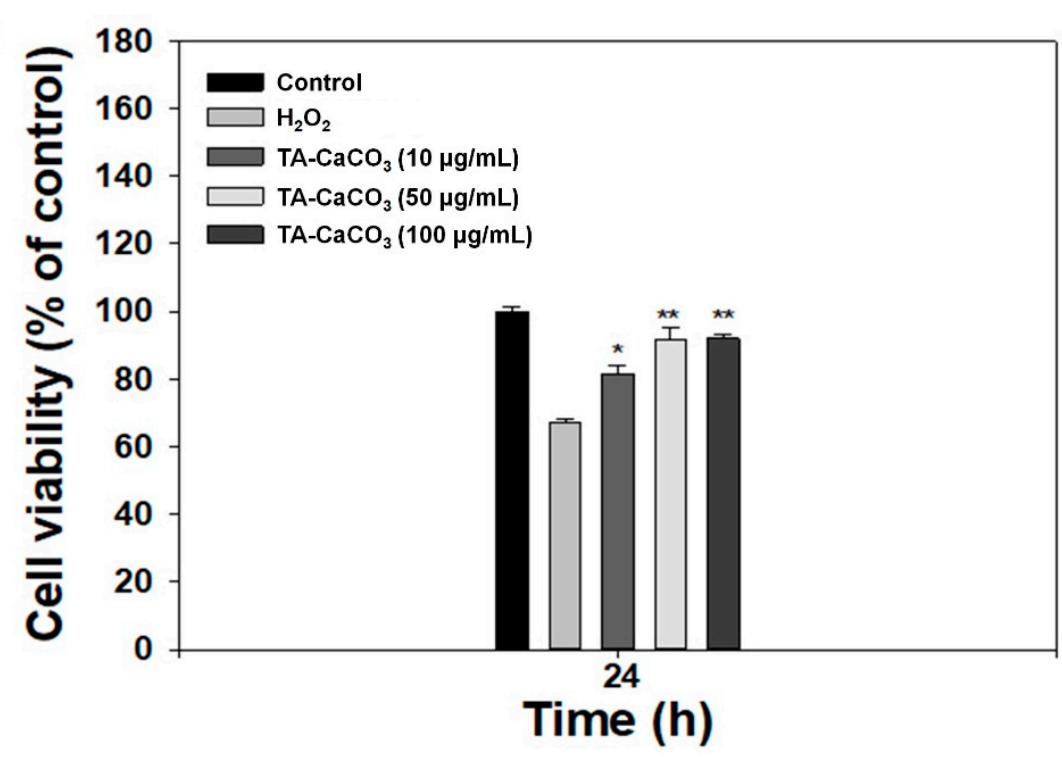

Figure 8. In vitro antioxidant effects of $\mathrm{TA}-\mathrm{CaCO}_{3}$. (a) Representative fluorescence images of intracellular ROS in chondrocytes treated with extracts containing different concentrations of 1:75 TA- $\mathrm{CaCO}_{3}$ for $24 \mathrm{~h}$ after pretreatment with $300 \mu \mathrm{M}$ of $\mathrm{H}_{2} \mathrm{O}_{2}$ for $30 \mathrm{~min}$. Scale bar: $20 \mu \mathrm{m}$. (b) Viability of chondrocytes treated with different concentrations of 1:75 $\mathrm{TA}-\mathrm{CaCO}_{3}$ for $24 \mathrm{~h}$ after pretreatment with $300 \mu \mathrm{M}$ of $\mathrm{H}_{2} \mathrm{O}_{2}$ for $30 \mathrm{~min}$. Results are expressed as the mean $\pm \mathrm{SD}(n=5) .{ }^{* *} p<0.01$ and $* p<0.05$.

Previous studies have reported that $\mathrm{H}_{2} \mathrm{O}_{2}$ can be toxic to cells because it produces hydroxyl radicals $[45,46]$. Substances with antioxidant properties prevent cell damage and protect the human body from free radicals or ROS by supplying electrons from antioxidants to the damaged cells $[47,48]$. Based on these facts, we investigated whether $\mathrm{TA}-\mathrm{CaCO}_{3}$ with antioxidant properties is effective in mediating cellular protection by measuring the viability of chondrocytes treated with $300 \mu \mathrm{M}$ of $\mathrm{H}_{2} \mathrm{O}_{2}$ (Figure $8 \mathrm{~b}$ ). In comparison with the control group, the chondrocytes cultured in $300 \mu \mathrm{M}$ of $\mathrm{H}_{2} \mathrm{O}_{2}$ showed a significant decrease in viability owing to the oxidative damage to cellular components [49]. However, the viability of the cells treated with different concentrations of $\mathrm{TA}-\mathrm{CaCO}_{3}$ significantly increased in a concentration-dependent manner, and was much higher than that of the chondrocytes treated with $300 \mu \mathrm{M}$ of $\mathrm{H}_{2} \mathrm{O}_{2}$ alone. Consistent with our previous studies showing that substances with antioxidant properties could protect the cells against ROS environments $[23,50], \mathrm{TA}-\mathrm{CaCO}_{3}$ effectively protected the cells and prevented cellular damage under ROS conditions. This protective effect might be associated with the effective radical-scavenging activity of TA molecules within $\mathrm{TA}-\mathrm{CaCO}$ materials. 


\section{Materials and Methods}

\subsection{Materials}

Calcium chloride dihydrate $\left(\mathrm{CaCl}_{2} \cdot 2 \mathrm{H}_{2} \mathrm{O}\right.$, abbreviated as $\left.\mathrm{CaCl}_{2}\right)$, sodium carbonate monohydrate $\left(\mathrm{Na}_{2} \mathrm{CO}_{3} \cdot \mathrm{H}_{2} \mathrm{O}\right.$, abbreviated as $\left.\mathrm{Na}_{2} \mathrm{CO}_{3}\right)$, TA, potassium bromide $(\mathrm{KBr}), \mathrm{BTB}$, $\mathrm{DPPH}$, sodium hydroxide $(\mathrm{NaOH}), 26 \%$ sodium chloride $(\mathrm{NaCl})$ solution, and hydrochloric acid $(\mathrm{HCl})$ were purchased from Sigma-Aldrich (St. Louis, MO, USA). Methanol $(\mathrm{MeOH}$, 99.5\%) and absolute ethanol (EtOH, 99.9\%) were provided by Samchun (Pyeongtaek, Korea) and DUKSAN (Ansan, Korea), respectively. Commercial $\mathrm{CaCO}_{3}$ nanopowder (purity: $98 \%$ ) was supplied by US Research Nanomaterials (Houston, TX, USA), and PBS by Lonza (Walkersville, MD, USA). SGF $(\mathrm{pH}=1.5)$ was prepared using ultra-pure water $(99.46 \% v / v)$, concentrated $\mathrm{HCl}(0.23 \% v / v)$, and $26 \% \mathrm{NaCl}$ solution $(0.21 \% v / v)$. To prepare the BTB solution, $10 \mathrm{mg}$ of BTB was dissolved in $1 \mathrm{~mL}$ of $4 \% \mathrm{NaOH}$ solution, and treated with $2 \mathrm{~mL}$ of $70 \% \mathrm{EtOH}(2 \mathrm{~mL})$ and $100 \mathrm{~mL}$ of ultra-pure water. Finally, a $10 \% \mathrm{NaOH}$ solution was added dropwise to the BTB solution when the color of the BTB solution changed to blue.

\subsection{Preparation of $\mathrm{TA}-\mathrm{CaCO}_{3}$}

For the preparation of TA-CaCO 3 materials, TA $(0.0294 \mathrm{mmol})$ was added to ultra-pure water $(5 \mathrm{~mL}, \mathrm{pH}=7.0)$ and stirred to dissolve at $800 \mathrm{rpm}$ for $1 \mathrm{~h}$. Different moles of $\mathrm{CaCl}_{2}$ $(0.735,1.47,2.20,2.94$, and $4.41 \mathrm{mmol})$ were dissolved in ultra-pure water $(3 \mathrm{~mL}, \mathrm{pH}=7.0)$. The prepared $\mathrm{CaCl}_{2}$ solutions were added to the TA solution and stirred at $800 \mathrm{rpm}$ for $2 \mathrm{~h}$. In addition, different moles of $\mathrm{Na}_{2} \mathrm{CO}_{3}(0.735,1.47,2.20,2.94$, and $4.41 \mathrm{mmol})$ were dissolved in ultra-pure water $(\mathrm{pH}=7.0)$ and added dropwise to the mixture solution of $\mathrm{TA}$ and $\mathrm{CaCl}_{2}$. The mixture was stirred at $800 \mathrm{rpm}$ for $24 \mathrm{~h}$, and the resulting solution was centrifuged at $1200 \mathrm{rpm}$ for $5 \mathrm{~min}$ and washed with ultrapure water. The collected $\mathrm{TA}-\mathrm{CaCO}_{3}$ materials were freeze-dried for two days. TA-CaCO 3 materials synthesized at different molar ratios of TA (molar ratio: 1), $\mathrm{CaCl}_{2}$ (molar ratios: 25, 50, 75, 100, and 150), and $\mathrm{Na}_{2} \mathrm{CO}_{3}$ (molar ratios of 25, 50, 75, 100, and 150) were named as follows: 1:25, 1:50, 1:75, 1:100, and 1:150 $\mathrm{TA}^{-\mathrm{CaCO}_{3}}$.

\subsection{Characterization of $\mathrm{TA}-\mathrm{CaCO}_{3}$}

For SEM analysis, the prepared TA- $\mathrm{CaCO}_{3}$ materials were coated with platinum. Then, the morphologies and sizes of the as-prepared $\mathrm{TA}-\mathrm{CaCO}_{3}$ materials were examined using field-emission scanning electron microscopy (FE-SEM, S-4700, Hitachi, Japan). For size analysis of the prepared TA- $\mathrm{CaCO}_{3}$, randomly selected individual particles of each TA- $\mathrm{CaCO}_{3}$ type were analyzed using ImageJ software (Version 1.47; US National Institutes of Health, Bethesda, MD, USA). The surface elemental composition of $\mathrm{TA}-\mathrm{CaCO}_{3}$ was examined using SEM-EDS.

To determine the amount of $\mathrm{Ca}^{2+}$ in TA-CaCO $3,1: 75$ TA- $\mathrm{CaCO}_{3}$ materials $(0.1 \mathrm{mg})$ were co-treated with nitric acid and $\mathrm{H}_{2} \mathrm{O}_{2}$, and the prepared samples were analyzed using ICP-OES (Optima 7300 DV, PerkinElmer, Waltham, MA, USA). Through ICP-OES analysis, the amount of TA and $\mathrm{CaCO}_{3}$ within $\mathrm{TA}-\mathrm{CaCO}_{3}$ was determined using a standard curve $\left(\mathrm{Y}=10,807 \mathrm{x}+1340.9 ; \mathrm{R}^{2}=0.999\right)$.

The prepared TA-CaCO 3 materials were characterized using FT-IR (Shimadzu 8400S, Kyoto, Japan). The FT-IR spectrum was acquired using a KBr pellet at a resolution of $4 \mathrm{~cm}^{-1}$ between 4,000 and $400 \mathrm{~cm}^{-1}$.

XRD and XPS analyses of 1:75 TA- $\mathrm{CaCO}_{3}$ were done by using a K-alpha+ (Thermo Scientific, Waltham, MA, USA) with $\mathrm{Cu} \mathrm{K} \alpha$ radiation and a D8 ADVANCE diffractometer (Bruker, Germany) with $\mathrm{Cu} \mathrm{K} \alpha$ radiation, respectively.

\subsection{Antacid Effects of $\mathrm{TA}-\mathrm{CaCO}_{3}$ Materials}

To investigate the in vitro antacid effects, $\mathrm{CaCO}_{3}(10 \mathrm{mg})$ or TA-CaCO $3(1: 75,10 \mathrm{mg})$ was dispersed in $2 \mathrm{~mL}$ of two different solutions, PBS $(\mathrm{pH}=7.4)$ and SGF $(\mathrm{pH}=1.5)$. Each solution $(1.4 \mathrm{~mL})$ was mixed well with the as-prepared BTB solution $(0.6 \mathrm{~mL})$ and stirred. After $1 \mathrm{~h}$, each solution was centrifuged at 13,500 rpm for $30 \mathrm{~min}$. The color of the collected 
supernatant was observed by taking photos, and the absorbance was analyzed using a UV/vis spectrophotometer (NEO-S490, NEOGEN, Daejeon, Korea).

\subsection{Antioxidant Effects of $\mathrm{TA}-\mathrm{CaCO}_{3}$ Materials}

To examine and compare the in vitro antioxidant effects, $\mathrm{CaCO}_{3}(1 \mathrm{mg})$ or TA-CaCO $(1 \mathrm{mg})$ was added to $1 \mathrm{~mL}$ of DPPH $(0.1 \mathrm{mM})$ dissolved in $\mathrm{MeOH}$ and reacted at $600 \mathrm{rpm}$ for $30 \mathrm{~min}$. Then, each solution was centrifuged at 5,500 rpm for $10 \mathrm{~min}$. The color of the supernatant was observed by taking photos, and the absorbance was recorded using a UV/vis spectrophotometer (NEO-S490).

\subsection{In Vitro Cytotoxicity and Anti-Inflammatory Effects}

Human knee articular chondrocytes were obtained from Lonza (Basel, Switzerland) and cultured in low-glucose Dulbecco's modified Eagle's medium (DMEM, Welgene, Seoul, Korea), supplemented with $10 \%$ fetal bovine serum (FBS) and $1 \%$ penicillin-streptomycin at $37^{\circ} \mathrm{C}$.

The cytotoxicity of TA- $\mathrm{CaCO}_{3}$ materials was determined with a cell counting kit-8 (CCK-8, Dojindo, Kumamoto, Japan). Chondrocytes $\left(1 \times 10^{4}\right.$ cells/well $)$ were seeded and incubated in a 96-well plate. After $24 \mathrm{~h}$ of incubation, $\mathrm{TA}-\mathrm{CaCO}_{3}$ materials at $0,10,50$, and $100 \mu \mathrm{g} / \mathrm{mL}$ concentrations were treated into the cells. After 24 or $48 \mathrm{~h}$ of exposure, the CCK-8 reagent was additionally treated to the cells for $1 \mathrm{~h}$, and the optical density was then recorded at $450 \mathrm{~nm}$ using a Multimode Reader. The cell viability of each group was represented as the percentage of viable cells versus the control group.

The in vitro anti-inflammatory effects of $\mathrm{TA}-\mathrm{CaCO}_{3}$ against LPS-stimulated chondrocytes were evaluated by determining the mRNA levels of pro-inflammatory factors using a real-time polymerase chain reaction $(\mathrm{PCR})$. Cells $\left(1 \times 10^{5}\right.$ cells / well) were seeded into 24-well plates and cultured overnight. Cells were simultaneously treated with both LPS $(100 \mathrm{ng} / \mathrm{mL})$ and different concentrations of TA- $\mathrm{CaCO}_{3}(0,10,50$, and $100 \mu \mathrm{g} / \mathrm{mL})$. After three-day treatment, the cells from each group were collected, and the total RNA was extracted using the RNeasy Plus Mini Kit (Qiagen, Valencia, CA, USA) according to the manufacturer's guidelines. Total RNA $(1 \mu \mathrm{g})$ was reverse-transcribed into cDNA using AccuPower RT PreMix (Bioneer, Daejeon, Korea). The sequences of the target gene primers are provided in Supplementary Materials (Table S1). Real-time PCR analysis was conducted using an ABI7300 Real-Time Thermal Cycler (Applied Biosystems, Foster City, CA, USA). The mRNA levels of the target genes were normalized to those of glyceraldehyde 3-phosphate dehydrogenase (GAPDH) and presented as relative levels.

\subsection{Antioxidant Effects of $\mathrm{TA}-\mathrm{CaCO}$ at the Cellular Level}

To investigate the antioxidant effects of $\mathrm{TA}-\mathrm{CaCO}_{3}$ at the cell level, we conducted DCFDA staining and a DCFDA assay. Cells $\left(1 \times 10^{4}\right.$ cells/well $)$ were seeded and incubated in 24-well plates with microscope cover glasses for $24 \mathrm{~h}$. Meanwhile, the extract solutions from the different concentrations of $\mathrm{TA}-\mathrm{CaCO}_{3}(0,10,50$, and $100 \mu \mathrm{g} / \mathrm{mL})$ were prepared by incubating them in DMEM medium at $37{ }^{\circ} \mathrm{C}$ for $24 \mathrm{~h}$, followed by collecting the supernatants from each group. Next, cells were treated with $300 \mu \mathrm{M}$ of $\mathrm{H}_{2} \mathrm{O}_{2}$ at $37^{\circ} \mathrm{C}$ for $30 \mathrm{~min}$, followed by additional treatment of the collected extract solutions from each group for $24 \mathrm{~h}$. After washing the cells with PBS, the cells were stained with DCFDA $(25 \mu \mathrm{M})$ for 30 min under a dark condition, washed with PBS, and then fixed with $3.7 \%$ paraformaldehyde for $30 \mathrm{~min}$. The fluorescence intensity within the cells was observed using a confocal laser scanning microscope (CLSM, LSM700, Zeiss, Germany).

\subsection{Protection of Cell Viability in the ROS Environment}

To investigate whether TA-CaCO 3 can protect cell viability in an ROS environment, chondrocytes $\left(1 \times 10^{5}\right.$ cells/well) were seeded in a 24-well culture plate. Then, the cells were treated with $300 \mu \mathrm{M}$ of $\mathrm{H}_{2} \mathrm{O}_{2}$ at $37^{\circ} \mathrm{C}$ for $30 \mathrm{~min}$, followed by additional treatment of TA- $\mathrm{CaCO}_{3}$ at 10,50 , and $100 \mu \mathrm{g} / \mathrm{mL}$ concentrations. After $24 \mathrm{~h}$ of treatment, the CCK-8 
(Dojindo) reagent was added to the cells for $1 \mathrm{~h}$. The supernatant from each group was transferred into a 96-well plate, and its optical density was measured at $450 \mathrm{~nm}$ using a multimode reader.

\section{Conclusions}

In the present study, we prepared TA-CaCO 3 materials by reacting TA with $\mathrm{CaCl}_{2}$ and $\mathrm{Na}_{2} \mathrm{CO}_{3}$, which led to the interaction between TA and $\mathrm{Ca}^{2+}$ ions, followed by nucleation of $\mathrm{CaCO}_{3}$. Micron-sized 1:75 TA-CaCO 3 materials (ranging from 3 to $6 \mu \mathrm{m}$ ) comprised small nanoparticles in a size range of $17-41 \mathrm{~nm}$. TA- $\mathrm{CaCO}_{3}$ materials could effectively neutralize the SGF solution and scavenge free radicals. In addition, these particles significantly suppressed the mRNA expression of pro-inflammatory cytokines and mediators and scavenged intracellular ROS in cells. Their anti-inflammatory and antioxidant activities protected chondrocytes from ROS. These results suggest that $\mathrm{TA}-\mathrm{CaCO}_{3}$ materials have excellent antacid, antioxidant, and anti-inflammatory properties. Importantly, TA molecules can undergo multiple interactions with nucleic acids, peptides, proteins, and polysaccharides. Furthermore, due to the molecular adsorption of $\mathrm{CaCO}_{3}$ materials, $\mathrm{CaCO}_{3}$-based materials can improve the incorporation efficacy of drugs. Thus, using $\mathrm{TA}-\mathrm{CaCO}_{3}$ materials, we will develop dual drug delivery systems that can ferry both a chemical drug and protein drug, and then apply them to treat inflammatory cells or diseases.

Supplementary Materials: The supplementary materials are available online at https:/ /www.mdpi. com/article/10.3390/ijms22094614/s1.

Author Contributions: Conceptualization, K.P. and S.-E.K.; methodology, S.-Y.J., H.H., H.-S.J. and S.C.; formal analysis, S.-Y.J., H.H., H.-S.J. and S.C.; writing-original draft preparation, S.-Y.J. and K.P.; writing - review and editing, H.-J.K., K.P. and S.-E.K.; funding acquisition, K.P. All authors have read and agreed to the published version of the manuscript.

Funding: This work was supported by grants from the National Research Foundation of Korea (NRF-2019M3A9E2066883) and by the Chung-Ang University Research Grants in 2020.

Institutional Review Board Statement: Not applicable.

Informed Consent Statement: Not applicable.

Data Availability Statement: Not applicable.

Conflicts of Interest: The authors declare no conflict of interest.

\section{References}

1. Fadeel, B.; Garcia-Bennett, A.E. Better safe than sorry: Understanding the toxicological properties of inorganic nanoparticles manufactured for biomedical applications. Adv. Drug Deliv. Rev. 2010, 62, 362-374. [CrossRef]

2. Wei, W.; Ma, G.H.; Hu, G.; Yu, D.; McLeish, T.; Su, Z.G.; Shen, Z.Y. Preparation of hierarchical hollow $\mathrm{CaCO}_{3}$ particles and the application as anticancer drug carrier. J. Am. Chem. Soc. 2008, 130, 15808-15810. [CrossRef] [PubMed]

3. Peng, C.; Zhao, Q.; Gao, C. Sustained delivery of doxorubicin by porous $\mathrm{CaCO}_{3}$ and chitosan/alginate multilayers-coated CaCO 3 microparticles. Colloids Surf. A Physicochem. Eng. Asp. 2010, 353, 132-139. [CrossRef]

4. Zhu, Y.; Yang, Z.; Dong, Z.; Gong, Y.; Hao, Y.; Tian, L.; Yang, X.; Liu, Z.; Feng, L. CaCO 3 -Assisted Preparation of pH-Responsive Immune-Modulating Nanoparticles for Augmented Chemo-Immunotherapy. Nano-Micro Lett. 2021, 13, 1-18. [CrossRef]

5. Park, D.J.; Min, K.H.; Lee, H.J.; Kim, K.; Kwon, I.C.; Jeong, S.Y.; Lee, S.C. Photosensitizer-loaded bubble-generating mineralized nanoparticles for ultrasound imaging and photodynamic therapy. J. Mater. Chem. B 2016, 4, 1219-1227. [CrossRef] [PubMed]

6. Koo, A.N.; Min, K.H.; Lee, H.J.; Jegal, J.H.; Lee, J.W.; Lee, S.C. Calcium Carbonate Mineralized Nanoparticles as an Intracellular Transporter of Cytochrome c for Cancer Therapy. Chem. Asian J. 2015, 10, 2380-2387. [CrossRef] [PubMed]

7. Roth, R.; Schoelkopf, J.; Huwyler, J.; Puchkov, M. Functionalized calcium carbonate microparticles for the delivery of proteins. Eur. J. Pharm. Biopharm. 2018, 122, 96-103. [CrossRef]

8. Biradar, S.; Ravichandran, P.; Gopikrishnan, R.; Goornavar, V.; Hall, J.C.; Ramesh, V.; Baluchamy, S.; Jeffers, R.B.; Ramesh, G.T. Calcium carbonate nanoparticles: Synthesis, characterization and biocompatibility. J. Nanosci. Nanotechnol. 2011, 11, 6868-6874. [CrossRef]

9. Ogomi, D.; Serizawa, T.; Akashi, M. Controlled release based on the dissolution of a calcium carbonate layer deposited on hydrogels. J. Control. Release 2005, 103, 315-323. [CrossRef] 
10. Min, K.H.; Min, H.S.; Lee, H.J.; Park, D.J.; Yhee, J.Y.; Kim, K.; Kwon, I.C.; Jeong, S.Y.; Silvestre, O.F.; Chen, X.; et al. pH-controlled gas-generating mineralized nanoparticles: A theranostic agent for ultrasound imaging and therapy of cancers. ACS Nano 2015, 9, 134-145. [CrossRef]

11. Rodriguez-Stanley, S.; Ahmed, T.; Zubaidi, S.; Riley, S.; Akbarali, H.I.; Mellow, M.H.; Miner, P.B. Calcium carbonate antacids alter esophageal motility in heartburn sufferers. Dig. Dis. Sci. 2004, 49, 1862-1867. [CrossRef]

12. Raliya, R.; Som, A.; Shetty, N.; Reed, N.; Achilefu, S.; Biswas, P. Nano-antacids enhance pH neutralization beyond their bulk counterparts: Synthesis and characterization. RSC Adv. 2016, 6, 54331-54335. [CrossRef]

13. Labieniec, M.; Gabryelak, T. Oxidatively modified proteins and DNA in digestive gland cells of the fresh-water mussel Unio tumidus in the presence of tannic acid and its derivatives. Mutat. Res. Toxicol. Environ. Mutagen. 2006, 603, 48-55. [CrossRef] [PubMed]

14. Turgut Cosan, D.; Saydam, F.; Ozbayer, C.; Doganer, F.; Soyocak, A.; Gunes, H.V.; Degirmenci, I.; Kurt, H.; Ustuner, M.C.; Bal, C. Impact of tannic acid on blood pressure, oxidative stress and urinary parameters in L-NNA-induced hypertensive rats. Cytotechnology 2015, 67, 97-105. [CrossRef] [PubMed]

15. Lopes, G.K.; Schulman, H.M.; Hermes-Lima, M. Polyphenol tannic acid inhibits hydroxyl radical formation from Fenton reaction by complexing ferrous ions. Biochim. Biophys. Acta Gen. Subj. 1999, 1472, 142-152. [CrossRef]

16. Andrade, R.G., Jr.; Dalvi, L.T.; Silva, J.M., Jr.; Lopes, G.K.; Alonso, A.; Hermes-Lima, M. The antioxidant effect of tannic acid on the in vitro copper-mediated formation of free radicals. Arch. Biochem. Biophys. 2005, 437, 1-9. [CrossRef]

17. Shukla, A.; Fang, J.C.; Puranam, S.; Jensen, F.R.; Hammond, P.T. Hemostatic multilayer coatings. Adv. Mater. 2012, $24,492-496$. [CrossRef]

18. Shin, M.; Ryu, J.H.; Park, J.P.; Kim, K.; Yang, J.W.; Lee, H. DNA/Tannic Acid Hybrid Gel Exhibiting Biodegradability, Extensibility, Tissue Adhesiveness, and Hemostatic Ability. Adv. Funct. Mater. 2015, 25, 1270-1278. [CrossRef]

19. Abouelmagd, S.A.; Meng, F.; Kim, B.K.; Hyun, H.; Yeo, Y. Tannic acid-mediated surface functionalization of polymeric nanoparticles. ACS Biomater. Sci. Eng. 2016, 2, 2294-2303. [CrossRef]

20. Sahiner, N.; Sagbas, S.; Aktas, N.; Silan, C. Inherently antioxidant and antimicrobial tannic acid release from poly(tannic acid) nanoparticles with controllable degradability. Colloids Surf. B Biointerfaces 2016, 142, 334-343. [CrossRef]

21. Shin, M.; Lee, H.A.; Lee, M.; Shin, Y.; Song, J.J.; Kang, S.W.; Nam, D.H.; Jeon, E.J.; Cho, M.; Do, M.; et al. Targeting protein and peptide therapeutics to the heart via tannic acid modification. Nat. Biomed. Eng. 2018, 2, 304-317. [CrossRef]

22. Hong, S.; Yeom, J.; Song, I.T.; Kang, S.M.; Lee, H.; Lee, H. Pyrogallol 2-Aminoethane: A Plant Flavonoid-Inspired Molecule for Material-Independent Surface Chemistry. Adv. Mater. Interfaces 2014, 1, 1400113. [CrossRef]

23. Lee, J.Y.; Lim, H.; Ahn, J.W.; Jang, D.; Lee, S.H.; Park, K.; Kim, S.E. Design of a 3D BMP-2-Delivering Tannylated PCL Scaffold and Its Anti-Oxidant, Anti-Inflammatory, and Osteogenic Effects In Vitro. Int. J. Mol. Sci. 2018, 19, 3602. [CrossRef]

24. Ninan, N.; Forget, A.; Shastri, V.P.; Voelcker, N.H.; Blencowe, A. Antibacterial and Anti-Inflammatory pH-Responsive Tannic AcidCarboxylated Agarose Composite Hydrogels for Wound Healing. ACS Appl. Mater. Interfaces 2016, 8, 28511-28521. [CrossRef] [PubMed]

25. Aromal, S.A.; Philip, D. Facile one-pot synthesis of gold nanoparticles using tannic acid and its application in catalysis. Phys. E Low Dimens. Syst. Nanostructures 2012, 44, 1692-1696. [CrossRef]

26. Park, J.S.; Song, Y.J.; Lim, Y.G.; Park, K. Facile Fabrication of Oxygen-Releasing Tannylated Calcium Peroxide Nanoparticles. Materials 2020, 13, 3864. [CrossRef]

27. Lopes, L.C.S.; Brito, L.M.; Bezerra, T.T.; Gomes, K.N.; Carvalho, F.A.A.; Chaves, M.H.; Cantanhede, W. Silver and gold nanoparticles from tannic acid: Synthesis, characterization and evaluation of antileishmanial and cytotoxic activities. An. Acad. Bras. Cienc. 2018, 90, 2679-2689. [CrossRef] [PubMed]

28. Abulateefeh, S.R.; Taha, M.O. Enhanced drug encapsulation and extended release profiles of calcium-alginate nanoparticles by using tannic acid as a bridging cross-linking agent. J. Microencapsul. 2015, 32, 96-105. [CrossRef]

29. Gokhe, U.B.; Koparkar, K.A.; Omanwar, S.K. Synthesis and fluorescence properties of $\mathrm{Ca}_{2} \mathrm{SiO}_{4}$ : $\mathrm{Dy}^{3+}$ phosphor for solid state lighting application. J. Mater. Sci. Mater. Electron. 2016, 27, 9286-9290. [CrossRef]

30. Andersen, F.A.; Brečević, L. Infrared spectra of amorphous and crystalline calcium carbonate. Acta Chem. Scand. 1991, 45, 1018-1024. [CrossRef]

31. Rodriguez-Blanco, J.D.; Shaw, S.; Benning, L.G. The kinetics and mechanisms of amorphous calcium carbonate (ACC) crystallization to calcite, via vaterite. Nanoscale 2011, 3, 265-271. [CrossRef]

32. Cakar, S.; Ozacar, M. Fe-tannic acid complex dye as photo sensitizer for different morphological ZnO based DSSCs. Spectrochim. Acta A Mol. Biomol. Spectrosc. 2016, 163, 79-88. [CrossRef] [PubMed]

33. Wojtas, M.; Wołcyrz, M.; Ożyhar, A.; Dobryszycki, P. Phosphorylation of Intrinsically Disordered Starmaker Protein Increases Its Ability To Control the Formation of Calcium Carbonate Crystals. Cryst. Growth Des. 2012, 12, 158-168. [CrossRef]

34. Dong, W.; Tu, C.; Tao, W.; Zhou, Y.; Tong, G.; Zheng, Y.; Li, Y.; Yan, D. Influence of the Mole Ratio of the Interacting to the Stabilizing Portion $\left(\mathrm{R}_{\mathrm{I} / \mathrm{S}}\right)$ in Hyperbranched Polymers on $\mathrm{CaCO}_{3}$ Crystallization: Synthesis of Highly Monodisperse Microspheres. Cryst. Growth Des. 2012, 12, 4053-4059. [CrossRef]

35. Torne, S.; Sheela, A.; Sarada, N.C. Investigation of the Role of the Alkalizing Agent in Sodium Alginate Liquid Anti-reflux Suspension. Curr. Drug Ther. 2020, 15, 53-60. [CrossRef] 
36. Puschett, J.B.; Rao, B.S.; Karandikar, B.M.; Matyjaszewski, K. Indicator characteristics of bromothymol blue derivatives. Talanta 1991, 38, 335-338. [CrossRef]

37. De Meyer, T.; Hemelsoet, K.; Van der Schueren, L.; Pauwels, E.; De Clerck, K.; Van Speybroeck, V. Investigating the halochromic properties of azo dyes in an aqueous environment by using a combined experimental and theoretical approach. Chem. Eur. J. 2012, 18, 8120-8129. [CrossRef]

38. Kedare, S.B.; Singh, R.P. Genesis and development of DPPH method of antioxidant assay. J. Food Sci. Technol. 2011, 48, 412-422. [CrossRef]

39. Cook, N.C.; Samman, S. Flavonoids-Chemistry, metabolism, cardioprotective effects, and dietary sources. J. Nutr. Biochem. 1996, 7, 66-76. [CrossRef]

40. Ozcelik, B.; Lee, J.H.; Min, D.B. Effects of Light, Oxygen, and pH on the Absorbance of 2,2-Diphenyl-1-picrylhydrazyl. J. Food Sci. 2003, 68, 487-490. [CrossRef]

41. Wu, Y.; Zhong, L.; Yu, Z.; Qi, J. Anti-neuroinflammatory effects of tannic acid against lipopolysaccharide-induced BV2 microglial cells via inhibition of NF-kappaB activation. Drug Dev. Res. 2019, 80, 262-268. [CrossRef]

42. Jeong, C.; Kim, S.E.; Shim, K.S.; Kim, H.J.; Song, M.H.; Park, K.; Song, H.R. Exploring the In Vivo Anti-Inflammatory Actions of Simvastatin-Loaded Porous Microspheres on Inflamed Tenocytes in a Collagenase-Induced Animal Model of Achilles Tendinitis. Int. J. Mol. Sci. 2018, 19, 820. [CrossRef] [PubMed]

43. Kang, S.; Yoon, J.S.; Lee, J.Y.; Kim, H.J.; Park, K.; Kim, S.E. Long-term local PDGF delivery using porous microspheres modified with heparin for tendon healing of rotator cuff tendinitis in a rabbit model. Carbohydr. Polym. 2019, 209, 372-381. [CrossRef] [PubMed]

44. Yeo, J.; Lee, J.; Yoon, S.; Kim, W.J. Tannic acid-based nanogel as an efficient anti-inflammatory agent. Biomater. Sci. 2020, 8, 1148-1159. [CrossRef]

45. Mashimo, M.; Kato, J.; Moss, J. ADP-ribosyl-acceptor hydrolase 3 regulates poly (ADP-ribose) degradation and cell death during oxidative stress. Proc. Natl. Acad. Sci. USA 2013, 110, 18964-18969. [CrossRef]

46. Chen, W.; Shen, X.; Hu, Y.; Xu, K.; Ran, Q.; Yu, Y.; Dai, L.; Yuan, Z.; Huang, L.; Shen, T.; et al. Surface functionalization of titanium implants with chitosan-catechol conjugate for suppression of ROS-induced cells damage and improvement of osteogenesis. Biomaterials 2017, 114, 82-96. [CrossRef]

47. Velioglu, Y.S.; Mazza, G.; Gao, L.; Oomah, B.D. Antioxidant Activity and Total Phenolics in Selected Fruits, Vegetables, and Grain Products. J. Agric. Food Chem. 1998, 46, 4113-4117. [CrossRef]

48. Rahman, M.M.; Islam, M.B.; Biswas, M.; Khurshid Alam, A.H. In vitro antioxidant and free radical scavenging activity of different parts of Tabebuia pallida growing in Bangladesh. BMC Res. Notes 2015, 8, 621. [CrossRef]

49. Valentine, J.S.; Wertz, D.L.; Lyons, T.J.; Liou, L.L.; Goto, J.J.; Gralla, E.B. The dark side of dioxygen biochemistry. Curr. Opin. Chem. Biol. 1998, 2, 253-262. [CrossRef]

50. Kim, S.E.; Choi, S.; Hong, J.Y.; Shim, K.S.; Kim, T.H.; Park, K.; Lee, S.H. Accelerated Osteogenic Differentiation of MC3T3-E1 Cells by Lactoferrin-Conjugated Nanodiamonds through Enhanced Anti-Oxidant and Anti-Inflammatory Effects. Nanomaterials 2019, 10, 50. [CrossRef] 